\title{
Operating Voltage and Loss Analysis of a Bi-Directional Isolated DC/DC Converter
}

\author{
Shigenori Inoue Student Member (Tokyo Institute of Technology) \\ Hirofumi Akagi Member (Tokyo Institute of Technology)
}

Keywords: bi-directional power flow, dc/dc converters, galvanic isolation, high-frequency transformers

This paper describes the bi-directional isolated dc/dc converter shown in Fig. 1 having a high-frequency transformer with a unity turn ratio, where the input and output dc voltages are different from each other. Few technical papers have dealt with the dc/dc converter under different dc voltages. Besides, no technical paper has demonstrated the operation of the $\mathrm{dc} / \mathrm{dc}$ converter rated around $10 \mathrm{~kW}$ under different dc voltages. However, voltage-adjusting capability may bring about a significant expansion of the application fields of the $\mathrm{dc} / \mathrm{dc}$ converter. Thus, this paper analyzes the relationship between operating dc voltages, transfered power, and power loss to determine how different the two dc voltages can be from each other without excessively increasing power loss. Then, experiments are conducted on the dc/dc converter rated at $360 \mathrm{~V}, 10 \mathrm{~kW}$, and $20 \mathrm{kHz}$, demonstrating bi-directional power flow under different dc voltages stably. The effect of the so-called "dead time" on the operating performance is also discussed in this paper.

Fig. 2 shows the calculated relationship between transfered power $P_{\mathrm{DC}}$ and the theoretical loss when one dc voltage is fixed at $320 \mathrm{~V}$ and the other is adjusted between $180 \mathrm{~V}$ and $360 \mathrm{~V}$. Note that Fig. 2 assumes the power transfer $P_{\mathrm{DC}}$ to be positive, and the theoretical loss consists of a snubber loss and an IGBT conducting loss excluding an IGBT switching loss and magnetic-component losses. The calculation was carried out under the condition where the snubber capacitor $C_{\text {snub }}=0.01 \mu \mathrm{F}$ and the voltage drop across each IGBT and diode is $1.5 \mathrm{~V}$ regardless of the current. Difference between $E_{1}$ and $E_{2}$ narrows the range of transfered power where ZVS (zerovoltage switching) operation is possible, resulting in an increased snubber loss. The lower $E_{2}$ becomes, the higher current is needed to transfer a given power, causing larger power loss than that $E_{1}=E_{2}=320 \mathrm{~V}$.

Thermal limit of $212 \mathrm{~W}$ is drawn as a dashed line in Fig. 2 based on the theoretical loss at $E_{1}=E_{2}=320 \mathrm{~V}$. When $E_{1}=320 \mathrm{~V}$ and $E_{2}=180 \mathrm{~V}$, the theoretical loss reaches the thermal limit at $P_{\mathrm{DC}}=5.6 \mathrm{~kW}$. The power loss or the thermal design of the $\mathrm{dc} / \mathrm{dc}$ converter determines the possible range of power transfer and the difference between the two dc voltages. As is mentioned in this paper, the peak value of the current $i_{1}$ also imposes limitation on the possible voltage difference. Despite the above-mentioned increased power loss, the operation under different dc voltages is useful and may expand the application field of the $\mathrm{dc} / \mathrm{dc}$ converter.

Experiments were conducted with $E_{1}$ fixed to $320 \mathrm{~V}$ and $E_{2}$ changed to be $320 \mathrm{~V}, 360 \mathrm{~V}, 260 \mathrm{~V}$, and $180 \mathrm{~V}$. Fig. 3 shows experimental waveforms of the $\mathrm{dc} / \mathrm{dc}$ converter when a power of $5 \mathrm{~kW}$ is transfered from Bridge 2 to Bridge $1\left(P_{\mathrm{DC}}=-5 \mathrm{~kW}\right)$ at $E_{1}=320 \mathrm{~V}$ and $E_{2}=180 \mathrm{~V}$. The peak value of $i_{1}$ was $60 \mathrm{~A}$ while its theoretical value was $66 \mathrm{~A}$. Although Bridge 2 was operated in hard switching

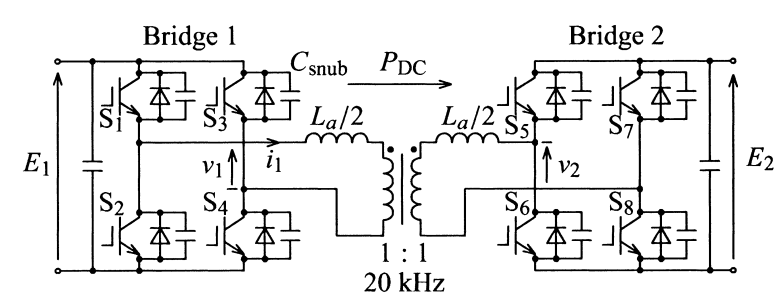

Fig. 1. A bi-directional isolated DC/DC converter

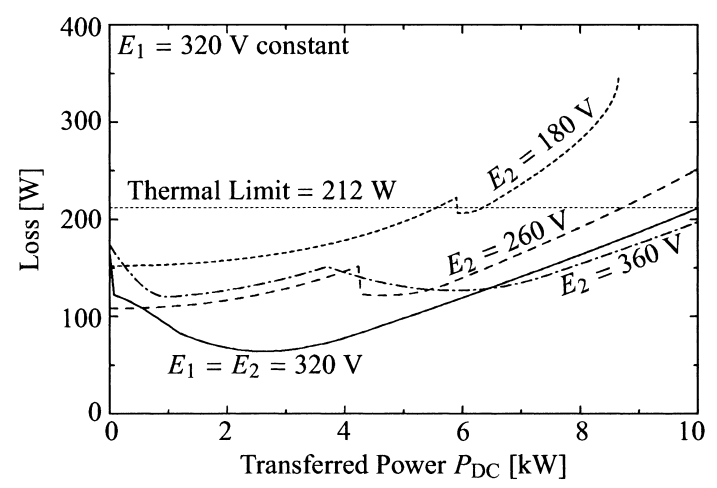

Fig. 2. Sum of theoretical conducting and snubber losses $P_{\text {theory }}=P_{\text {cond }}+P_{\text {snub }}$ when $P_{\mathrm{DC}}$ is positive
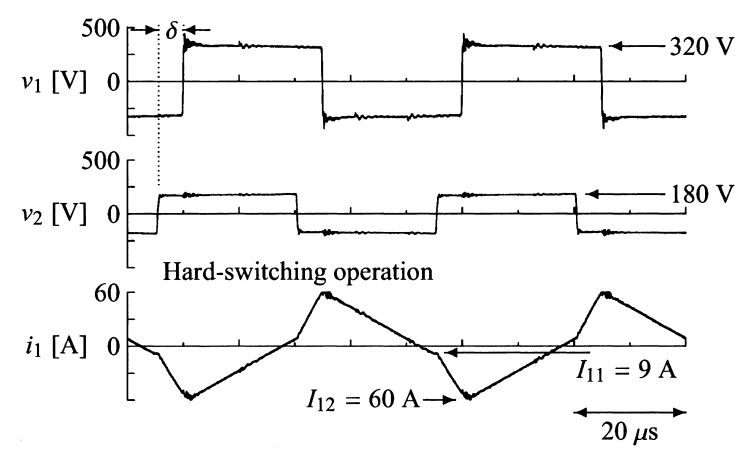

Fig. 3. Experimental waveforms when $E_{1}=320 \mathrm{~V}$, $E_{2}=180 \mathrm{~V}, \delta=-41^{\circ}$, and $P_{\mathrm{DC}}=-5 \mathrm{~kW}$

manner, the $\mathrm{dc} / \mathrm{dc}$ converter stably delivered $5 \mathrm{~kW}$.

The theoretical analysis and the experimental result in this paper suggests that the bi-directional isolated $\mathrm{dc} / \mathrm{dc}$ converter may have wide-spread applications such as energy storage systems and hybrid vehicles because it can stably operate with its input and output dc voltage different from each other. 


\title{
双方向絶縁形 DC/DC コンバータの動作電圧と損失解析
}

\author{
学生員 井上 重徳* 正 員 赤木 泰文*
}

\section{Operating Voltage and Loss Analysis of a Bi-Directional Isolated DC/DC Converter}

Shigenori Inoue*, Student Member, Hirofumi Akagi*, Member

This paper describes a bi-directional isolated dc/dc converter having a high-frequency transformer with a unity turn ratio, where the input and output dc voltages are different from each other. Theoretical analysis reveals that power loss in the dc/dc converter, as well as peak current flowing in the high-frequency transformer and auxiliary inductors, imposes limitations on the maximum transferable power. The $10-\mathrm{kW}, 20-\mathrm{kHz} \mathrm{dc} / \mathrm{dc}$ converter designed and constructed in this paper is operated with one dc voltage fixed to $320 \mathrm{~V}$ and the other ranging between $180 \mathrm{~V}$ and $360 \mathrm{~V}$ without excessively increased power loss. The effect of the so-called "dead time" on the operating performance is also discussed in this paper. Such wide range of dc voltage may bring about a various application fields to the dc/dc converter.

キーワード : 双方向電力フロー, DC/DC コンバータ, 電気的絶縁, 高周波変圧器

Keywords: bi-directional power flow, dc/dc converters, galvanic isolation, high-frequency transformers

\section{1. まえがき}

入出力間の電気的絶縁を確保しつつ, 双方向に電力を伝送 できる DC/DCコンバータが注目されている。中でも, 図 1 に示す DC/DC コンバータ (1)(2) は，2台の単相フルブリッジ コンバータ（Bridge 1, Bridge 2）を外付けインダクタ $L_{a}$ と高周波変圧器を介して結合し, 入出力回路が高周波変圧 器を中心に左右対称である点に特長がある。同様に，ハー フブリッジコンバータを用いる回路方式 (3)(4) や, ソフトス イッチング回路を追加した方式 ${ }^{(5)(6)}$ が発表されている。文 献 (7) は $2 \mathrm{~kW}$ 級の双方向絶縁形 DC/DC コンバータに関し て, 図 1 の回路を含む 4 種類の回路方式を比較・検討して いるが，実験検証は行っていない。

1991 年に発表された図 1 の DC/DC コンバータ (1) は第 1 世代 IGBT を使用し，フェライトコアを用いた高周波変圧 器で構成されていた。このことを考慮すると, 直流入出力 間 $\left(E_{1} \rightarrow E_{2}\right)$ の電力変換効率は 90 92\% と推定できる。 このため, 図 1 の DC/DC コンバータはパワーエレクトロニ クス研究者・技術者にはほとんど注目されず, 応用も検討さ れなかった。しかし，パワーデバイス技術と磁性材料技術の 進歩によって, 実用レベルまで効率を改善できる可能性があ る。著者らは, 最新のトレンチゲート IGBT とナノ結晶軟

\footnotetext{
* 東京工業大学 大学院理工学研究科電気電子工学専攻

T 152-8552 東京都目黒区大岡山 2-12-1, S3-17

Department of Electrical and Electronic Engineering,

Tokyo Institute of Technology

S3-17, 2-12-1, O-okayama, Meguro, Tokyo, 152-8552, Japan
}

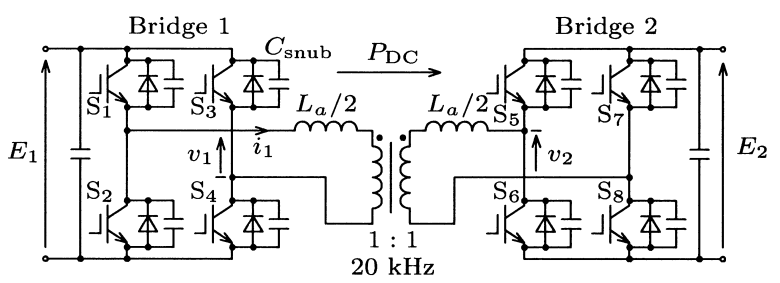

図 1 双方向絶縁形 DC/DC コンバータ

Fig. 1. A bi-directional isolated dc/dc converter.

磁性材料（日立金属・ファインメット）を用いた DC/DCコ ンバータ $(350 \mathrm{~V}, 10 \mathrm{~kW}, 20 \mathrm{kHz})$ を設計・製作し, $97 \%$ と いう高効率動作を実証した。さらに, SiC-MOSFET/JFET などの次世代パワーデバイスの使用を前提として, 図 1 の DC/DC コンバータをコア回路とする $3.3 \mathrm{kV} / 6.6 \mathrm{kV}$ 電力変 換システムを検討した ${ }^{(8)(9)}$ 。

図 1 の DC/DC コンバータは直流電圧が異なる $\left(E_{1} \neq E_{2}\right)$ 場合にも双方向電力伝送が可能である。しかし, 動作電圧 の範囲や, 動作電圧と電力損失の関係を詳細に検討し, 実 証した論文は発表されていない。そこで本論文では, 双方 向絶縁形 DC/DC コンバータ $(10 \mathrm{~kW}, 20 \mathrm{kHz})$ の一方の直 流電圧 $E_{1}=320 \mathrm{~V}$ 一定に維持し, 他方の直流電圧 $E_{2}$ を可 変パラメータとして電力損失とピーク電流を解析する。こ れにより，直流電圧 $E_{2}$ の下限を明らかにする。なお， $E_{2}$ の上限はパワーデバイスの耐圧や高周波変圧器の鉄心の磁 気飽和によって制限されることは明らかであるため, 本論 文では $E_{2}$ の下限を検討する。また, 理論解析と同様に, 
$E_{1}=320 \mathrm{~V}$ 一定に維持した状態で， $E_{2}=180 \mathrm{~V} \sim 360 \mathrm{~V}$ に 変化させる電力伝送試験を行い, 理論解析結果と実験結果 の比較を行う。さらに，デッドタイムが伝送電力及ぼす影 響を考察する。

図 1 では高周波変圧器の巻数比を 1: 1 としているが, 直流定格電圧に応じて巻数比を設定できる。さらに，50〜 100\%の動作電圧範囲を実現できれば, 図 1 の DC/DC コン バータの応用範囲は大きく拡大するものと考える。

\section{2. 双方向絶縁形 DC/DC コンバータの動作原理と 近似理論波形}

図 2 は, 図 1 において直流電圧 $E_{1}<E_{2}$ の場合の理論 波形の概念図である。ただし, 図 2 ではIGBT と還流ダイ オードを理想素子とし, デッドタイム, 配線抵抗, 変圧器 の鉄損・銅損を無視している。直流電圧 $E_{2}$ の下限を理論 的に検討するにあたり，簡単のために図 2 の波形を用いる。 2 台の単相フルブリッジコンバータは $20 \mathrm{kHz}$ かつ $180^{\circ}$ 通 電の方形波電圧 $v_{1}$ と $v_{2}$ を発生させる。伝送電力 $P_{\mathrm{DC}}$ は $v_{1}$ と $v_{2}$ の位相差 $\delta[\mathrm{rad}]$ で決定され, 次式で表される。

$$
P_{\mathrm{DC}}=\frac{E_{1} E_{2}}{\omega L}\left(\delta-\frac{\delta^{2}}{\pi}\right) .
$$

ただし， $\omega=2 \pi f$ であり, $f$ はスイッチング周波数 $\left(v_{1}, v_{2}\right.$ の周波数）である。また， $L$ は高周波変圧器の漏れインダ クタンス $L_{\text {trans }}$ と外付けインダクタのインダクタンス $L_{a}$ の 和 $\left(L_{\mathrm{trans}}+L_{a}\right)$ である。

以下，スイッチングの瞬間における電流 $i_{1}$ の瞬時值 $I_{11}$ と $I_{12}$ を図 2 のように定義する。 $I_{11}, I_{12}$ は次式で表わさ れ，以降のスナバ損失の計算に用いる。

$$
\begin{aligned}
& I_{11}=-\frac{\left(E_{1}+E_{2}\right) \delta+\left(E_{1}-E_{2}\right)(\pi-\delta)}{2 \omega L} \\
& I_{12}=\frac{\left(E_{1}+E_{2}\right) \delta-\left(E_{1}-E_{2}\right)(\pi-\delta)}{2 \omega L} \cdots
\end{aligned}
$$

$I_{11}$ は Bridge 1 の交流端電圧 $v_{1}$ が負から正に変化する瞬間 の電流 $i_{1}$ の瞬時值であり， $I_{12}$ は Bridge 2 の交流端電圧 $v_{2}$ が負から正に変化する瞬間の電流 $i_{1}$ の瞬時值である。本論 文では $I_{11}$ と $I_{12}$ を「スイッチング時の電流」と呼ぶ。また,

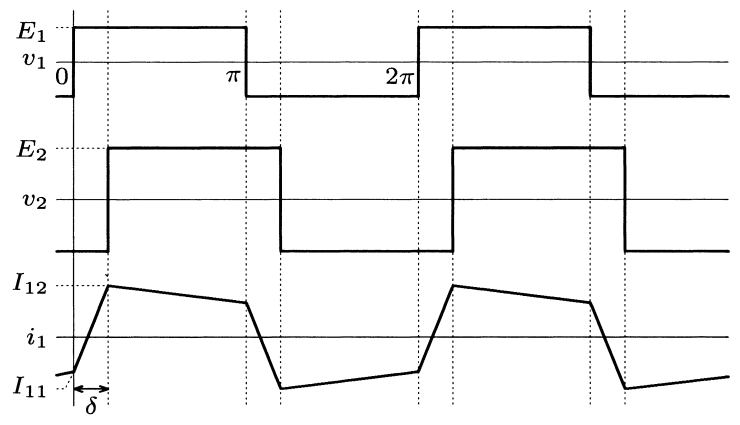

図 2 損失解析に用いる近似理論波形 $\left(E_{1}<E_{2}\right)$

Fig. 2. Simplified theoretical waveforms used to analyze the power losses when $E_{1}<E_{2}$. $i_{1}$ の実効值を $I_{1}$, 絶対值の平均值を〈|i 1|\rangle と表記する。

上記の無視した要因によって，実際の回路の $v_{1}, v_{2}, i_{1}$ の波形は, 㛜密には図 2 の波形とは異なる。また, 本論文 における電力損失の理論解析では, $\delta>0$ の場合の解析のみ を行う。図 1 の双方向絶縁形 DC/DC コンバータは高周波 変圧器を中心に対称回路であるため, $\delta>0$ として解析して も一般性を失わない。 $\delta<0$ の場合, 電力は Bridge 2 から Bridge 1 へ伝送される。この場合， $\delta ， E_{1} ， E_{2}$ をそれぞれ $-\delta, E_{2}, E_{1}$ に置き換えることで解析できる。以下では, ス ナバ損失, IGBT の導通損失, 高周波変圧器・外付けインダ クタの銅損を計算する。また， $i_{1}$ のピーク值 $I_{1 \text { peak }}$ と伝送 電力の関係を考察する。これにより, 直流電圧 $E_{1}=320 \mathrm{~V}$ 一定に維持した場合の $E_{2}$ の下限を明らかにする。

\section{3. スナバ損失の解析}

〈3.1〉 回路の動作点と ZVS 条件 図 1 では, スイッ チング損失低減とサージ電圧抑制を目的として各 IGBT と 並列にスナバキャパシタ $C_{\text {snub }}$ を接続している。IGBT ター ンオン時の $C_{\mathrm{snub}}$ の蓄積電荷は電力損失となる。本論文で はこの損失をスナバ損失と呼ぶ。

直流電圧 $E_{1}=E_{2}$ で, かつ, 伝送電力 $P_{\mathrm{DC}}$ が定格付近で ある場合, 各 IGBT はZVS（zero-voltage switching）動作 するため, スナバ損失は発生しない。しかし， $P_{\mathrm{DC}}$ が小さ い場合や $E_{1} \neq E_{2}$ である場合には，ZVS が実現できない 動作条件が存在する ${ }^{(1)(2)}$ 。図 3 に Bridge 2 がハードスイッ チング動作する場合の理論波形の概念図を示す。図 3 は, 図 2 と同じく $E_{1}<E_{2}$ の場合であるが, 伝送電力 $P_{\mathrm{DC}}$ が小 さい場合の波形である。Bridge 1 のスイッチング時の電流 $I_{11}>0$ であり, このような条件では, Bridge 1 で還流ダイ オードの逆回復が起こる。したがって, ハードスイッチン グ動作となる。

2 台の単相フルブリッジコンバータの IGBT ターンオン 時の動作は, 直流電圧 $E_{1}, E_{2}$, 位相差 $\delta$, デッドタイム $T_{D}$ から，（1）ハードスイッチング，（2 不完全ZVS 動作，(3) ZVS 動作，に分類できる。以下では，主にBridge 1 を対象 とするが，Bridge 2 に関しても同様である。

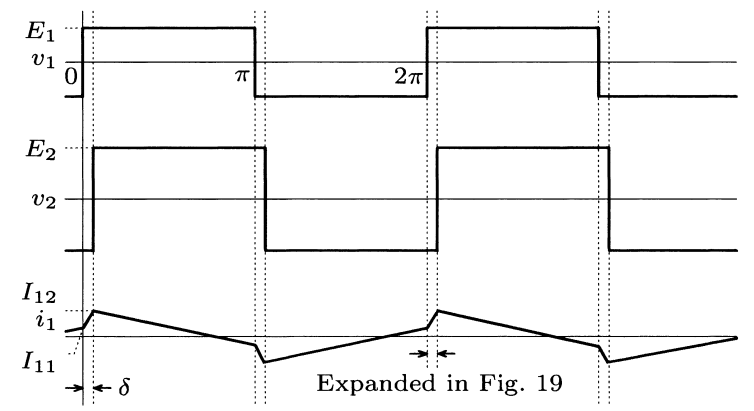

図 $3 I_{11}>0$ となり, Bridge 1 がハードスイッチング となる場合の動作波形

Fig. 3. Waveforms when a positive $I_{11}$ forces Bridge 1 to operate in hard-switching manner. 


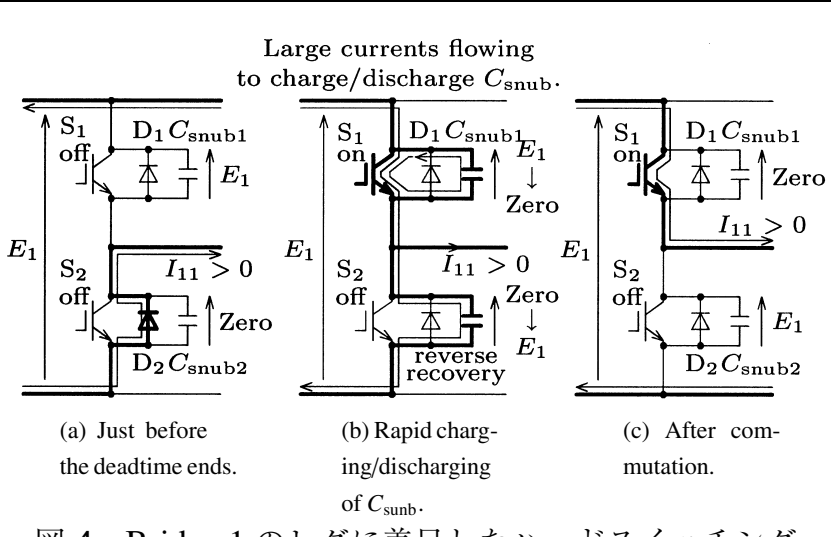

図 4 Bridge 1 のレグに着目したハードスイッチング

Fig. 4. Hard switching on one leg in Bridge 1.

\section{$\langle 3 \cdot 2\rangle$ スナバ損失の計算}

〈3·2・1〉 ハードスイッチング 図 4 に Bridge 1 が ハードスイッチング動作をする場合の 1 レグ $\left(\mathrm{S}_{1}, \mathrm{~S}_{2}\right)$ の回 路モードを示す。直流電圧 $E_{1}<E_{2}$ であり, かつ位相差 $\delta に$ 関する次式を満足する場合，スイッチング時の電流 $I_{11} \geq 0$ となり Bridge 1 はハードスイッチング動作となる ${ }^{(1)}$ 。

$$
\delta \leq \frac{E_{2}-E_{1}}{2 E_{2}} \pi \ldots \ldots \ldots \ldots \ldots \ldots \ldots \ldots \ldots \ldots \ldots \ldots \ldots \ldots \ldots \ldots
$$

上式を満足する場合, 低圧側の単相フルブリッジコンバー タがハードスイッチング動作する。

図 4 は， $S_{2}$ をターンオフした後， $S_{1}$ をターンオンするま でのデッドタイムとその後の回路動作を示している。デッ ドタイム終了直前, $\mathrm{S}_{1}$ のスナバキャパシタ $C_{\mathrm{snub} 1}$ は直流電 圧 $E_{1}$ に充電されている（図 $\left.4(a)\right) 。 S_{1}$ がターンオンすると, $\mathrm{S}_{2}$ の還流ダイオード $\mathrm{D}_{2}$ は逆回復し, $C_{\mathrm{snub} 1}$ は $E_{1}$ から零ま で放電し， $C_{\text {snub2 }}$ は零から $E_{1}$ まで充電する $($ 図 4(b))。こ のとき, $\mathrm{S}_{1}$ の等価的な抵抗が $C_{\mathrm{snub} 1}$ と $C_{\mathrm{snub} 2}$ の充放電電流 を制限する。ジュール損失 $W_{\mathrm{snub} 1}=C_{\mathrm{snub}} E_{1}^{2}$ が発生する†。 単相フルブリッジコンバータではレグが 2 個あり, $20 \mathrm{kHz}$ 動作の 1 周期中に上記の動作が 2 回行われる。したがって,

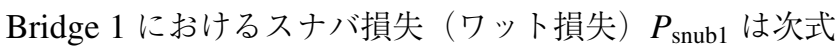
で表わされる。

$$
P_{\text {snub } 1}=4 W_{\text {snub1 }} f=4 C_{\text {snub }} E_{1}^{2} f
$$

Bridge 2 がハードスイッチング動作となる条件は, $E_{1}>E_{2}$ かつ，(4) 式の $E_{1}$ と $E_{2}$ を入れ替えた式が成立することで ある。

〈3.2・2 Z ZVS 動作 図 5 に Bridge 1 がZVS 動作す る場合の 1 レグ $\left(\mathrm{S}_{1}\right.$ と $\left.\mathrm{S}_{2}\right)$ の回路モードを示す。スイッ チング時の電流 $I_{11}<0$ である場合， $I_{11}$ の大きさに応じて ZVS 動作か不完全 ZVS 動作かが決定する。

図 5(a) はデッドタイム開始直前の回路モードであり，大 きさ $\left|I_{11}\right|$ の電流が $\mathrm{S}_{2}$ を流れている。 $\mathrm{S}_{2}$ がターンオフして デッドタイムが開始すると，電流は $C_{\text {snub1 }}$ と $C_{\text {snub2 }}$ に分流

† $W_{\text {snub1 }}$ はスイッチング 1 回あたり，1 レグあたりのジュール損失 を表わす。また， $C_{\text {snub }}=C_{\text {snub1 }}=C_{\text {snub2 }}$ である。

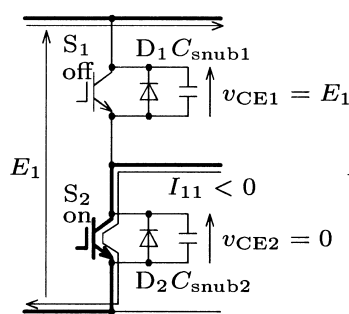

(a) Just before

the deadtime starts.

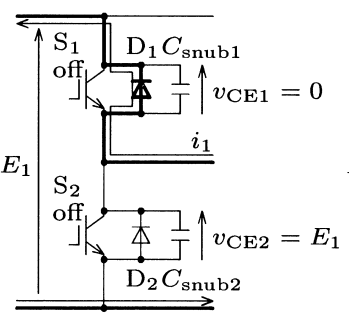

(c) Diode free wheeling.

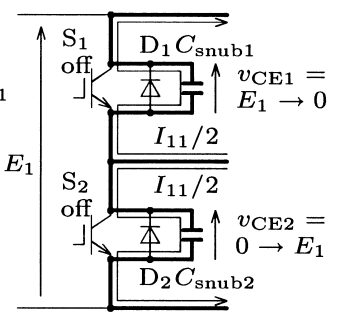

(b) Just after the deadtime starts.

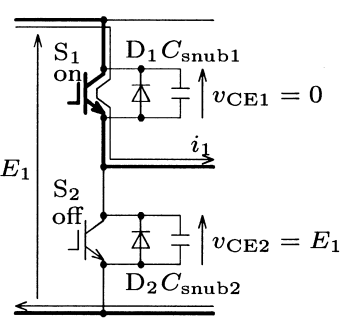

(d) Current polarity alternates after the deadtime.
図 5 Bridge 1 のレグに着目したZVS 動作

Fig. 5. ZVS on one leg in Bridge 1.

し, $C_{\text {snub1 } 1}, C_{\text {snub2 }}$ とインダクタンス $L$ (図 1 を参照) の共振 が開始する (図 5(b))。この電流は $C_{\text {snub1 }}$ を放電し, $C_{\text {snub2 }}$ を充電する。 $C_{\mathrm{snub} 2}$ が直流電圧 $E_{1}$ まで充電され， $C_{\mathrm{snub} 1}$ が 零まで放電されると, $\mathrm{S}_{1}$ の還流ダイオード $\mathrm{D}_{1}$ が導通し, 共振モードが終了する（図 5(c)）。図 5(c) の期間中に $\mathrm{S}_{1}$ の ゲート信号を与えれば, ZVS でターンオンできる。この場 合, スナバ損失は発生しない $\left(P_{\text {snub1 }}=0\right)$ 。

$\langle\mathbf{3 \cdot 2 \cdot 3 \rangle}$ 不完全 ZVS 動作 スイッチング時の電流 $I_{11}<0$ かつ $\left|I_{11}\right|<I_{\min }$ である場合, $C_{\mathrm{snub} 2}$ は $E_{1}$ まで充電 されず, $C_{\mathrm{snub} 1}$ は零まで放電されない。ただし， $I_{\min }$ は ZVS 動作に必要な最小電流であり, 次式で表わされる(2)。

$$
\begin{gathered}
I_{\min }=\frac{2 \sqrt{E_{1} E_{2}}}{Z_{\mathrm{zvs}}} . \\
Z_{\mathrm{zvs}}=\sqrt{\frac{L}{C_{\mathrm{snub}}}} \cdots
\end{gathered}
$$

この場合, 回路の動作は図 5(c) を経由することなく, 図 5(b) から図 5(d) に移る。したがって, $C_{\text {snub1 }}$ に電荷が蓄積され ている状態で $\mathrm{S}_{1}$ がターンオンするため, スナバ損失が発生 する。本論文ではこれを不完全 ZVS 動作と呼ぶ。

不完全 ZVS 動作に伴うスナバ損失は, 以下のように求め られる。図 5(b) における $S_{1}$ のコレクタ・エミッタ間電圧 $v_{\mathrm{CE} 1}(t)$ は, 回路の過渡解析から次式で計算できる。

$$
\begin{aligned}
v_{\mathrm{CE} 1}(t)= & \frac{\left(E_{1}+E_{2}\right)+\left(E_{1}-E_{2}\right) \cos \omega_{\mathrm{zvs}} t}{2} \\
& -\frac{Z_{\mathrm{zvs}}\left|I_{11}\right| \sin \omega_{\mathrm{zvs}} t}{2} \ldots \ldots \ldots \ldots
\end{aligned}
$$

ただし，上式中の $t$ はデッドタイム開始の瞬間を零とする 時刻であり， $\omega_{\mathrm{zvs}}$ は $C_{\mathrm{snub}}$ と $L$ の共振角周波数である。 


$$
\omega_{\mathrm{zvs}}=\frac{1}{\sqrt{L C_{\mathrm{snub}}}}
$$

スナバ損失 $P_{\text {snub1 }}$ はデッドタイム開始時 $(t=0)$ から終了 時までの時間，すなわちデッドタイム $T_{D}$ に依存する。ス イッチング 1 回，1レグあたり，ジュール損失 $W_{\text {snub1 }}$ が発 生する。

$$
\begin{aligned}
W_{\text {snub } 1}= & \frac{1}{2} C_{\text {snub }}\left\{v_{\mathrm{CE} 1}\left(T_{D}\right)\right\}^{2} \\
& +\frac{1}{2} C_{\text {snub }}\left\{E_{1}-v_{\mathrm{CE} 2}\left(T_{D}\right)\right\}^{2} \\
= & C_{\text {snub }}\left\{v_{\mathrm{CE} 1}\left(T_{D}\right)\right\}^{2} \ldots \ldots \ldots
\end{aligned}
$$

したがって，スナバ損失（ワット損失） $P_{\text {snub1 は次式で表 }}$ される。

$$
P_{\text {snub1 }}=4 f C_{\text {snub }}\left\{v_{\mathrm{CE} 1}\left(T_{D}\right)\right\}^{2}
$$

Bridge 2 では, (8) 式の $v_{\mathrm{CE} 1}, E_{1}, E_{2}, I_{11}$ を, $v_{\mathrm{CE} 5}, E_{2}$, $-E_{1}, I_{12}$ に置き換えることで, $v_{\mathrm{CE} 5}$ を求めることで，最終 的には (11) 式からスナバ損失 $P_{\mathrm{snub} 2}$ を計算できる。

(5), (11) 式から明らかなように，スナバ損失は $C_{\text {snub }}$ に 比例する。したがって，単相フルブリッジコンバータは浮 遊インダクタンスを最小化する実装を行い， $C_{\text {snub }}$ はサージ 電圧を許容值以下に抑制する最小值を採用する必要がある。

\section{IGBT の導通損失と高周波変圧器, 外付けインダ クタの銅損の解析}

本論文では IGBT のオン電圧 $V_{\mathrm{CE}(\mathrm{sat})}$ とその還流ダイオー ドの電圧降下 $V_{F}$ を, 電流に無関係に $V_{\mathrm{CE}(\mathrm{sat})}=V_{F}=1.5 \mathrm{~V}$ と近似する ${ }^{(9)}$ 。電流 $i_{1}$ の絶対值の平均值 $\left\langle\left|i_{1}\right|\right\rangle$ から IGBT と 還流ダイオードの導通損失 $P_{\text {cond }}$ を求め, 実効值 $I_{1}$ から高 周波変圧器, 外付けインダクタの銅損 $P_{\text {copp }}$ を求める。

$\langle 4 \cdot 1\rangle$ 電流 $i_{1}$ の絶対值の平均值 $\left\langle\left|i_{1}\right|\right\rangle$ と導通損失

Bridge 1 または Bridge 2 がハードスイッチング動作 である場合, 図 3 から電流 $i_{1}$ の絶対值の平均值 $\left\langle\left|i_{1}\right|\right\rangle=$ $1 / \pi \int_{0}^{\pi}\left|i_{1}(\theta)\right| d \theta$ は次式で表される。

$$
\left\langle\left|i_{1}\right|\right\rangle=\frac{1}{\omega L}\left\{\frac{E_{1} E_{2}}{\left|E_{1}-E_{2}\right|} \frac{\delta^{2}}{\pi}+\left|E_{1}-E_{2}\right| \frac{\pi}{4}\right\} .
$$

また, Bridge 1，2 がZVS 動作または不完全 ZVS 動作で ある場合，〈|i |\rangle は次式で表される。

$$
\left\langle\left|i_{1}\right|\right\rangle=\frac{E_{1} E_{2}}{\omega L\left(E_{1}+E_{2}\right)}\left\{-\frac{\delta^{2}}{\pi}+2 \delta+\frac{\left(E_{1}-E_{2}\right)^{2}}{E_{1} E_{2}} \frac{\pi}{4}\right\}
$$

直流電圧 $E_{1}, E_{2}$, 位相差 $\delta$ から $I_{11}, I_{12}$ を計算し, どちら かの単相フルブリッジコンバータがハードスイッチング動 作の場合は (12) 式を適用し，ZVS 動作または不完全 ZVS 動作の場合は (13) 式を適用して導通損失 $P_{\text {cond }}$ を次式のよ うに求める。

$$
P_{\text {cond }}=2\left(V_{\mathrm{CE}(\mathrm{sat})}+V_{F}\right) \cdot\left\langle\left|i_{1}\right|\right\rangle
$$

なお, $P_{\text {cond }}$ は Bridge 1 と Bridge 2 の導通損失の和である。 $\langle 4 \cdot 2\rangle$ 電流 $i_{1}$ の実効值 $I_{1}$ 電流 $i_{1}$ の実効值 $I_{1}$ は, ハードスイッチング動作の場合も，ZVS 動作または不完全 ZVS 動作の場合も同一の式で表わされる。

$$
I_{1}=\frac{\sqrt{E_{1} E_{2}}}{\omega L} \sqrt{-\frac{4}{3 \pi} \delta^{3}+\delta^{2}+\frac{\pi^{2}}{12} \frac{\left(E_{1}-E_{2}\right)^{2}}{E_{1} E_{2}}}
$$

上式に基づき, 高周波変圧器と外付けインダクタの銅損 $P_{\text {copp }}$ を求める。

$$
P_{\text {copp }}=\left(R_{\text {trans }}+R_{a}\right) \cdot I_{1}^{2}
$$

ここで, $R_{\mathrm{trans}}=17 \mathrm{~m} \Omega$ は高周波変圧器の巻線抵抗, $R_{a}=$ $10 \mathrm{~m} \Omega$ は外付けインダクタの巻線抵抗である。

\section{5. 電力損失（熱設計）と $\boldsymbol{E}_{2}$ の下限}

$\langle\mathbf{5} \cdot \mathbf{1}\rangle$ 解析結果と実験結果の比較 以上の解析結果 と実験回路 $(10 \mathrm{~kW} ， 20 \mathrm{kHz})$ での測定結果を比較・検討 する。困 6 に全電力損失を測定するための実験回路を示 す。また，表 1 に図 6 の回路定数を示す。なお，本節では $E_{1}=E_{2}=350 \mathrm{~V}$ として電力損失の解析と測定を行った。 図 6 の $E$ は直流電源装置である。伝送電力 $P_{\mathrm{DC}}$ は Bridge 1 と 2 を間を循環し, 直流電源装置 $E$ の出力電力は $\mathrm{DC} / \mathrm{DC}$ コンバータの全損失 $P_{\text {loss }}$ に等しく， $P_{\text {loss }}$ を高精度かつ容 易に測定できる。フェライトコア（PC44）とリッツ線で構 成した外付けインダクタ $L_{a}=40 \mu \mathrm{H}$ を, 高周波変圧器の漏 れインダクタンス $L_{\text {trans }}=1.6 \mu \mathrm{H}$ と直列に接続している†。

図 7 は, 電力損失の理論值と実験結果の比較である。実 線は各損失の理論值の和であり, 理論的な全損失 $P_{\text {theory }}$ で ある。ただし, IGBT のスイッチング損失 $P_{\mathrm{sw}}$, 高周波変圧 器の鉄損 $P_{\text {core(tr), }}$ 外付けインダクタ $L_{a}$ の鉄損 $P_{\text {core(ind) }}$ 含まない。破線は導通損失 $P_{\text {cond }}$ の理論值, 点線はスナバ 損失 $P_{\text {snub }}$ の理論值である。

定格電力 $P_{\mathrm{DC}}=10 \mathrm{~kW}$ 送電時, 導通損失 $P_{\text {cond }}$ の理論值 は $189 \mathrm{~W}$, スナバ損失 $P_{\text {snub }}$ の理論值は零, 銅損 $P_{\text {copp }}$ の理 論值は $50 \mathrm{~W}$ であり, 理論的な全損失 $P_{\text {theory }}=239 \mathrm{~W}$ であ る。これに対して, 実験回路における全損失 $P_{\text {loss }}=400 \mathrm{~W}$ であった。その差 $P_{\text {loss }}-P_{\text {theory }}=161 \mathrm{~W}$ は, IGBT のスイッ チング損失 $P_{\mathrm{sw}}$, 高周波変圧器の鉄損 $P_{\mathrm{core}(\mathrm{tr})}$, 外付けインダ ク夕 $L_{a}$ の鉄損 $P_{\text {core(tr) }}$ の和に相当すると考えられる。著者 らの前論文 ${ }^{(9)}$ では, 定格 $P_{\mathrm{DC}}=10 \mathrm{~kW}$ 送電時, $P_{\mathrm{sw}}=90 \mathrm{~W}$, $P_{\text {core(tr) }}=20 \mathrm{~W}, P_{\text {core(ind) }}=9 \mathrm{~W}$ であると結論した。本論文 の実験回路では, 外付けインダクタ $L_{a}$ のインダクタンスを 倍増 $(20 \mu \mathrm{H} \rightarrow 40 \mu \mathrm{H})$ したことにより, 外付けインダク 夕の鉄損も倍増し $P_{\text {core(ind) }}=18 \mathrm{~W}$ であると考えられるけ†。 したがって，前章までに解析していない損失の和は

$$
P_{\mathrm{sw}}+P_{\text {core(tr) }}+P_{\text {core(tr) }}=128 \mathrm{~W}
$$

\footnotetext{
†文献 (9) では $L_{a}=20 \mu \mathrm{H}$ であった。本論文では $E_{1} \neq E_{2}$ の条件下 で $i_{1}$ のピーク值増加を抑制するために $L_{a}=40 \mu \mathrm{H}$ とした。

故文献 (9) では, $10 \mu \mathrm{H}$ のインダク夕を 2 個直列に接続しており, 本 論文では 4 個直列に接続している。
} 


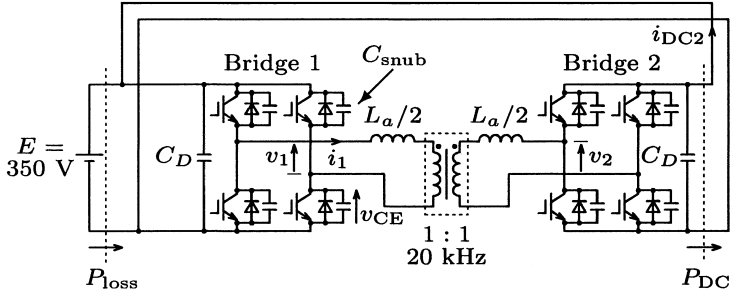

図 6 双方向絶縁形 DC/DC コンバータ

$\left(E_{1}=E_{2}=E\right)$ の全電力損失測定のための実験 回路

Fig. 6. Experimental circuit to measure the overall power loss of the dc/dc converter in case of $E_{1}=E_{2}=E$.

\section{表 $1 \mathrm{DC} / \mathrm{DC}$ コンバータの回路定数}

Table 1. Circuit parameters of the $\mathrm{dc} / \mathrm{dc}$ converter.

\begin{tabular}{l|c|r}
\hline \hline Rated power & $P$ & $10 \mathrm{~kW}$ \\
\hline Rated DC voltage & $E_{1}, E_{2}$ & $360 \mathrm{~V}$ \\
\hline DC capacitor & $C_{D}$ & $7,100 \mu \mathrm{F}$ \\
\hline Unit capacitance constant & $H$ & $46 \mathrm{~ms}$ \\
\hline Transformer core material & & Finemet FT-3M \\
\hline Transformer turn ratio & & $1: 1$ \\
\hline Transformer leakage inductance & $L_{\text {trans }}$ & $1.6 \mu \mathrm{H}(1.6 \%)$ \\
\hline Transformer winding resistance & $R_{\text {trans }}$ & $17 \mathrm{~m} \Omega(0.13 \%)$ \\
\hline Auxiliary inductor & $L_{a} / 2$ & $20 \mu \mathrm{H}(19 \%)$ \\
\hline Auxiliary inductor core material & & Ferrite $(\mathrm{PC} 44)$ \\
\hline Inductor winding resistance & $R_{a} / 2$ & $10 \mathrm{~m} \Omega(0.077 \%)$ \\
\hline Snubber Capacitor & $C_{\text {snub }}$ & $0.01 \mu \mathrm{F}(1.6 \%)$ \\
\hline Switching Frequency & $f$ & $20 \mathrm{kHz}$ \\
\hline
\end{tabular}

Based on single-phase $360 \mathrm{~V}, 10 \mathrm{~kW}$, and $20 \mathrm{kHz}$.

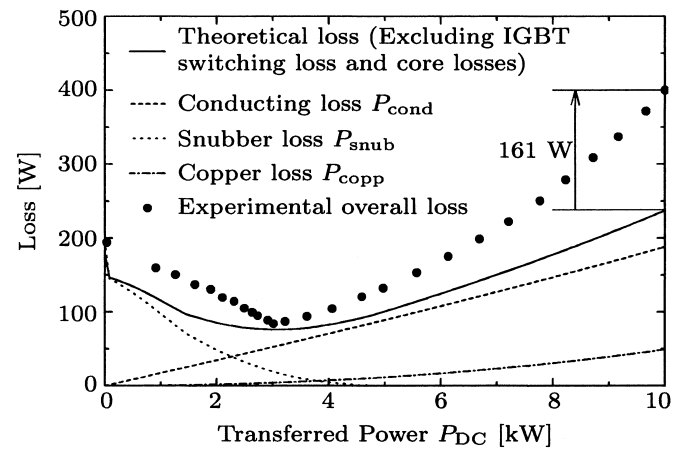

図 $7 E_{1}=E_{2}=350 \mathrm{~V}$ における電力損失の解析 結果と実験結果の比較

Fig. 7. Comparison between calculated and experimental power losses at $E_{1}=E_{2}=350 \mathrm{~V}$.

であり，上述の $161 \mathrm{~W}$ に対する誤差は $161 \mathrm{~W}-128 \mathrm{~W}=$ $33 \mathrm{~W}$ となる。これは, 伝送電力 $P_{\mathrm{DC}}=10 \mathrm{~kW}$ に比較して $0.33 \%$, 全損失 $P_{\text {loss }}=400 \mathrm{~W}$ に対して $8.3 \%$ あり，許容 誤差と考える。

$\langle\mathbf{5 \cdot 2}\rangle$ 熱設計限界と $\boldsymbol{E}_{\mathbf{2}}$ の下限 図 8 に，伝送電力 $P_{\mathrm{DC}}>0$ の場合における電力損失の理論解析結果 $P_{\text {theory }}=$ $P_{\text {cond }}+P_{\text {snub }}$ を示す。ただし, 図 8 では $E_{1}=320 \mathrm{~V}$ 一定に 維持し, 可変パラメータとして $E_{2}=180 \mathrm{~V} \sim 360 \mathrm{~V}$ に変化 させている。また，高周波変圧器と外付けインダクタの銅 損 $P_{\text {copp }}$ を含まない。 $E_{1}=E_{2}=320 \mathrm{~V}$ の場合に比較して,

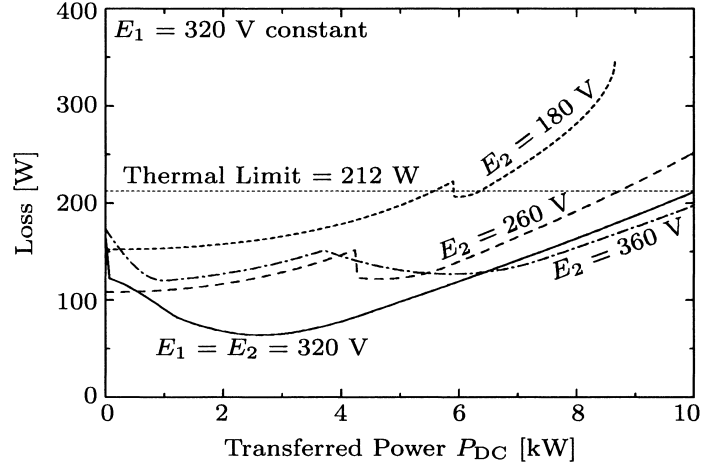

図 8 導通損失 $P_{\text {cond }}$ とスナバ損失 $P_{\text {snub }}$ の理論値 の和 $P_{\text {theory }} \quad\left(P_{\mathrm{DC}}>0\right.$ の場合 $)$

Fig. 8. Sum of theoretical conducting and snubber losses $P_{\text {theory }}=P_{\text {cond }}+P_{\text {snub }}$ when $P_{\mathrm{DC}}$ is positive.

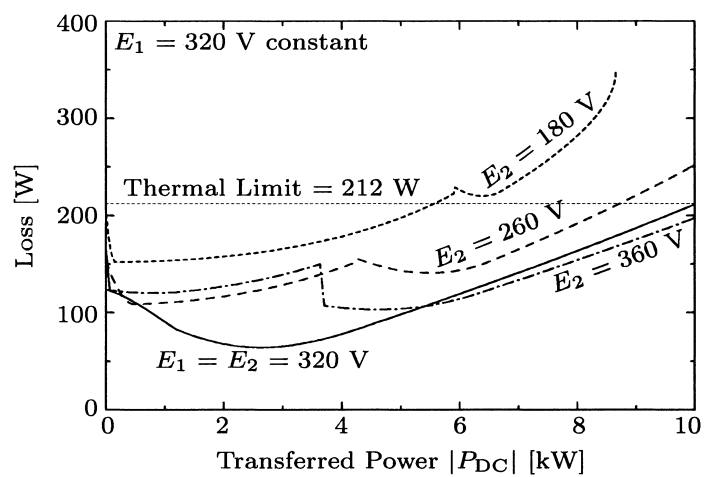

困 9 導通損失 $P_{\text {cond }}$ とスナバ損失 $P_{\text {snub }}$ の理論值 の和 $P_{\text {theory }} \quad\left(P_{\mathrm{DC}}<0\right.$ の場合 $)$

Fig. 9. Sum of theoretical conducting and snubber losses $P_{\text {theory }}=P_{\text {cond }}+P_{\text {snub }}$ when $P_{\mathrm{DC}}$ is negative.

$E_{1} \neq E_{2}$ の場合には，ZVS 動作領域が狭くなり，スナバ損 失が増加する。また, $E_{2}=180 \mathrm{~V}, 260 \mathrm{~V}$ の場合, 電力伝 送に必要な電流が増加し，これに伴って導通損失が増加す る。 $E_{2}=360 \mathrm{~V}$ の場合, 同様の理由で $P_{\mathrm{DC}}=10 \mathrm{~kW}$ 付近 の電力損失が $E_{2}=320 \mathrm{~V}$ の場合よりも小さくなる。

図 8 では直流電圧 $E_{1}=E_{2}=320 \mathrm{~V}$, 伝送電力 $P_{\mathrm{DC}}=$ $10 \mathrm{~kW}$ における $P_{\text {cond }}+P_{\text {snub }}=212 \mathrm{~W}$ を熱設計限界 (Thermal Limit）として規定しているお。この理由は以下の通り である。本論文の DC/DC コンバータでは IGBT の損失が 支配的である (9)。実験回路では，4 個の IGBT モジュール (two-in-one) を 1 台の放熱器に実装し, IGBT モジュール と変圧器 ·外付けインダクタの間の熱的な結合は無視でき る。したがって, 電力損失の増加に伴って IGBT モジュー ル（正確には半導体チップ）の温度上昇が最大伝送電力を 決定すると考えられるので，本論文ではIGBT の損失のみ を熱設計限界として考慮する。図 8 から明らかなように, $E_{2}=180 \mathrm{~V}$ の場合, $P_{\mathrm{DC}}>5.6 \mathrm{~kW}$ で熱設計限界を超える

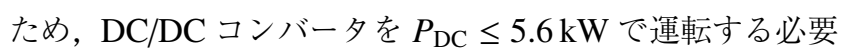

†この熱設計限界では, 高周波変圧器や外付けインダク夕の損失を 考慮していない。 
がある。また, $E_{2}=260 \mathrm{~V}$ の場合, $P_{\mathrm{DC}}>8.6 \mathrm{~kW}$ で熱設 計限界を超えるため， DC/DC コンバータを $P_{\mathrm{DC}} \leq 8.6 \mathrm{~kW}$ で運転する必要がある。このように, 電力損失 (熱設計) と 伝送電力が $E_{2}$ の下限を決定する。

図 9 に, 伝送電力 $P_{\mathrm{DC}}<0$ の場合に扔ける電力損失の 理論解析結果 $P_{\text {theory }}=P_{\text {cond }}+P_{\text {snub }}$ を示す。ただし, 図 9 では横軸を絶対值 $\left|P_{\mathrm{DC}}\right|$ で表わしている。 $E_{2}=180 \mathrm{~V}$ の場 合, $\left|P_{\mathrm{DC}}\right|>5.5 \mathrm{~kW}$ で熱設計限界を超え, $E_{2}=260 \mathrm{~V}$ の場 合, $\left|P_{\mathrm{DC}}\right|>8.7 \mathrm{~kW}$ で熱設計限界を超える。

\section{6. 外付けインダクタ $L_{a}$ の電流容量と $E_{2}$ の下限}

外付けインダクタ $L_{a}$ にはフェライトコア $(\mathrm{PC} 44)$ を用い ている。鉄心の磁気飽和防止のため, 電流 $i_{1}$ のピーク值を $L_{a}$ の定格電流以下に制限する必要がある。 $E_{2}$ の低下に伴っ て $i_{1}$ のピーク值が増加し, $L_{a}$ の定格電流が $E_{2}$ の下限を決 定する。 $i_{1}$ のピーク值 $I_{1 \text { peak }}$ は, $E_{1}>E_{2}$ の場合には $I_{11} に$ 等しく, $E_{1}<E_{2}$ の場合には $I_{12}$ と等しい。 $L_{a}$ の許容最大 電流を $60 \mathrm{~A}$ とすると, DC/DC コンバー夕を $I_{1 \text { peak }} \leq 60 \mathrm{~A}$ で運転する必要がある。

図 10 に $I_{1 \text { peak }} \leq 60 \mathrm{~A}$ に制限した場合に送電可能な電力を 示す。ただし，実線は送電可能な電力を表わし，点 $(\bullet$ 印) は 次章に示す実験波形の動作点である。 $E_{2}=180 \mathrm{~V}$ の場合, $P_{\mathrm{DC}}>5.1 \mathrm{~kW}$ で $I_{1 \text { peak }}>60 \mathrm{~A}$ となる。また, $E_{2}=260 \mathrm{~V}$

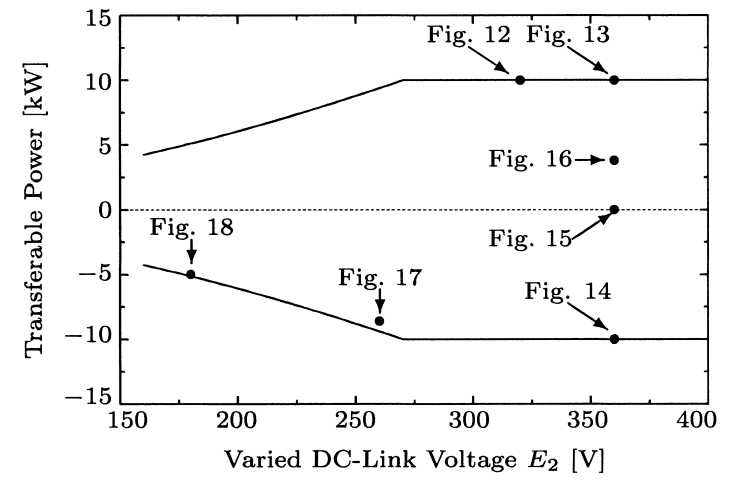

図 10 電流 $i_{1}$ のピーク值を $I_{1 \text { peak }} \leq 60 \mathrm{~A}$ に制限 した場合の送電可能電力と実験波形の動作点

Fig. 10. Transferable powers when limiting the peak value of current $i_{1}$ under $60 \mathrm{~A}$, and their operating points in experiments.
の場合, $P_{\mathrm{DC}}>9.4 \mathrm{~kW}$ で $I_{1 \text { peak }}>60 \mathrm{~A}$ となる。

\section{7. 実験結果}

実験では $E_{1} \neq E_{2}$ である場合における双方向絶縁形 DC/DC コンバータの電力伝送試験を行う。この場合, 図 6 のように Bridge 1 と 2 の直流リンクを接続できないの で, 全損失の高精度な測定は困難である。本章の実験では, $E_{1}=320 \mathrm{~V}$ 一定に維持し， $E_{2}$ を $320 \mathrm{~V}, 360 \mathrm{~V}, 260 \mathrm{~V}$, $180 \mathrm{~V}$ に変化させて DC/DC コンバータの双方向電力伝送 を検証し，損失解析の前提である (2)，(3)，(4) 式の妥当性 を確認する。

$\left\langle\mathbf{7 \cdot 1 \rangle}\right.$ 実験回路 図 11 に DC/DC コンバータ $\left(E_{1} \neq\right.$ $\left.E_{2}\right)$ の双方向電力伝送試験装置を, 表 1 に双方向絶縁形 DC/DC コンバータの回路定数を示す。DC/DC コンバー 夕の直流入出力端に 2 台の系統連系 PWM コンバー夕 $(200 \mathrm{~V}, 10 \mathrm{~kW})$ を接続し，それらの交流端は PCC（Point of Common Coupling) に接続されている。したがって, $P_{\mathrm{DC}}>0$ である場合, 電力は $\mathrm{PCC} \rightarrow \mathrm{PWM}$ コンバータ $1 \rightarrow$ Bridge $1 \rightarrow$ Bridge $2 \rightarrow$ PWM コンバータ $2 \rightarrow$ PCC を循環する。なお，PWM コンバータのキャリア周波数は $10 \mathrm{kHz}$ である。伝送電力 $P_{\mathrm{DC}}$ は, Bridge 2 側の直流電力

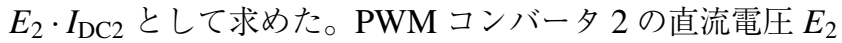
は $320 \mathrm{~V} \sim 360 \mathrm{~V}$ の範囲で調整できる。

$\langle 7 \cdot 2\rangle \quad E_{2} \geq 320 \mathrm{~V}$ における電力伝送試験

図 12 に

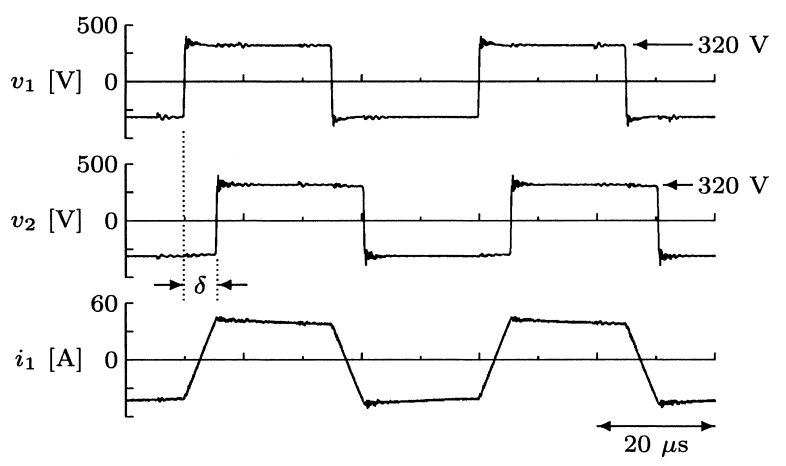

困 $12 E_{1}=E_{2}=320 \mathrm{~V}, \delta=40^{\circ}, P_{\mathrm{DC}}=10 \mathrm{~kW}$ における実験波形

Fig. 12. Experimental waveforms when $E_{1}=E_{2}=$ $320 \mathrm{~V}, \delta=40^{\circ}$, and $P_{\mathrm{DC}}=10 \mathrm{~kW}$.

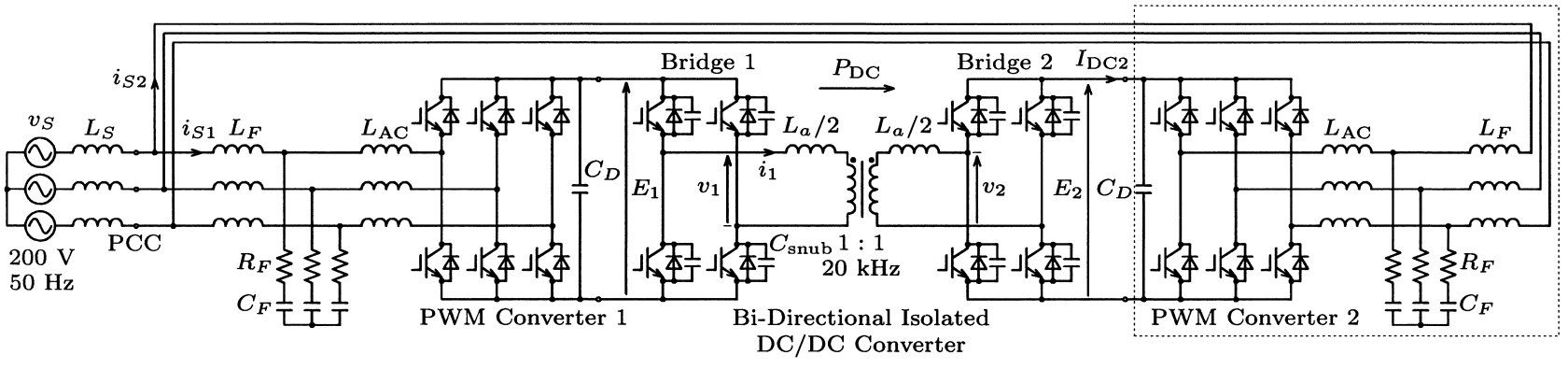

図 11 双方向絶縁形 DC/DC コンバータ $\left(E_{1} \neq E_{2}\right)$ の双方向電力伝送試験装置

Fig. 11. Test bed of bi-directional power transfer of the dc/dc converter in case of $E_{1} \neq E_{2}$. 


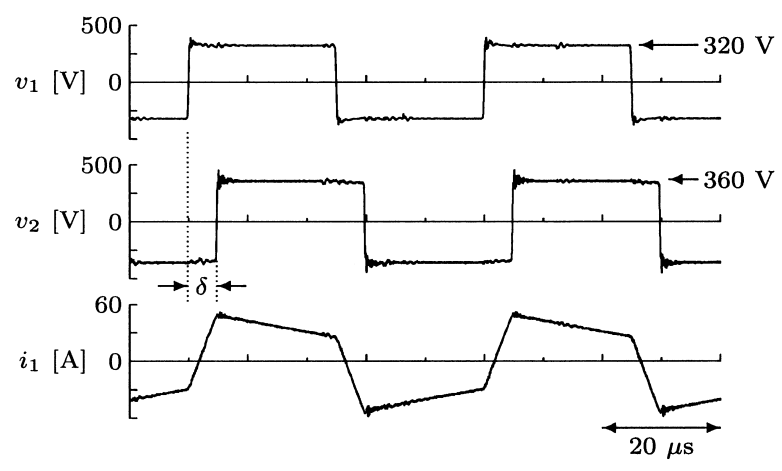

図 $13 E_{1}=320 \mathrm{~V}, E_{2}=360 \mathrm{~V}, \delta=35^{\circ}$, $P_{\mathrm{DC}}=10 \mathrm{~kW}$ における実験波形

Fig. 13. Experimental waveforms when $E_{1}=320 \mathrm{~V}$, $E_{2}=360 \mathrm{~V}, \delta=35^{\circ}$, and $P_{\mathrm{DC}}=10 \mathrm{~kW}$.
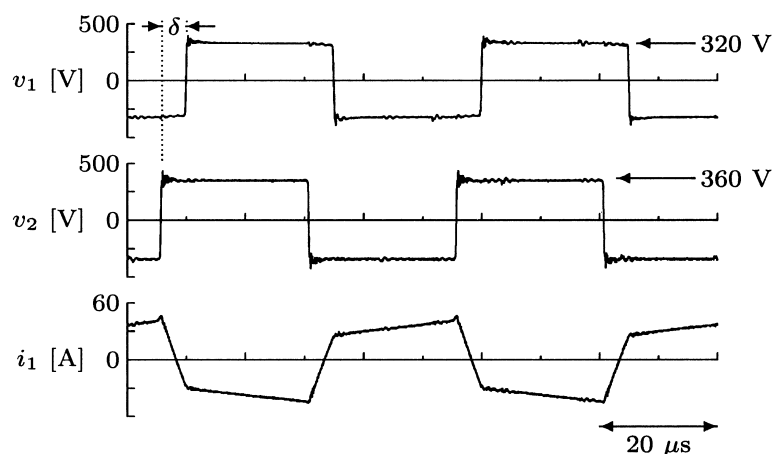

図 $14 E_{1}=320 \mathrm{~V}, E_{2}=360 \mathrm{~V}, \delta=-31^{\circ}$, $P_{\mathrm{DC}}=-10 \mathrm{~kW}$ における実験波形

Fig. 14. Experimental waveforms when $E_{1}=320 \mathrm{~V}$, $E_{2}=360 \mathrm{~V}, \delta=-31^{\circ}$, and $P_{\mathrm{DC}}=-10 \mathrm{~kW}$.

$E_{1}=E_{2}=320 \mathrm{~V}$ の場合の実験波形を示す。位相差 $\delta=40^{\circ}$, $P_{\mathrm{DC}}=10 \mathrm{~kW}$ の電力を伝送している。 $E_{1}=E_{2}$ であるた め, 電流 $i_{1}$ の波形は台形波となる。

図 13 , 図 14 に, $E_{1}=320 \mathrm{~V}, E_{2}=360 \mathrm{~V}$ で, $10 \mathrm{~kW}$ の 電力を伝送している場合の実験波形を示す。ただし，図 13 は $P_{\mathrm{DC}}=10 \mathrm{~kW} \quad\left(E_{1} \rightarrow E_{2}\right)$ の場合であり, 図 14 は $P_{\mathrm{DC}}=-10 \mathrm{~kW} \quad\left(E_{1} \leftarrow E_{2}\right)$ の場合の波形である。これよ り, $E_{1} \neq E_{2}$ における $10 \mathrm{~kW}$ の双方向電力伝送を実証した。

図 15 に $P_{\mathrm{DC}}=0 \mathrm{~kW}$ における実験波形を示す。制御回 路では $\delta=6.5^{\circ}$ に設定しているが，デッドタイムの影響の ため， $v_{1}$ と $v_{2}$ の位相差は実質的にほぼ零になる。この場 合の $i_{1}$ は三角波となり，低圧側単相フルブリッジコンバー 夕（Bridge 1）はハードスイッチング動作となる。図 16 は $I_{11}=0 \mathrm{~A}$ となる場合の実験波形であり，(4) 式で等号が成立 する場合の波形である。このとき， $\delta=18^{\circ}$ であり，(4) 式 から計算される值 $\left(=10^{\circ}\right)$ と比較して誤差が大きいが，こ れは理論解析で無視したデッドタイム $T_{D}=600 \mathrm{~ns}$ の影響 によるものと考えられる。デッドタイムの影響は $\langle 7 \cdot 4\rangle$ 節 で述べる。

$\langle\mathbf{7} \cdot \mathbf{3}\rangle \boldsymbol{E}_{\mathbf{2}}<\mathbf{3 2 0} \mathrm{V}$ における電力伝送試験系統連系 $\mathrm{PWM}$ コンバータでは $E_{2}<320 \mathrm{~V}$ の電力伝送試験は不可能
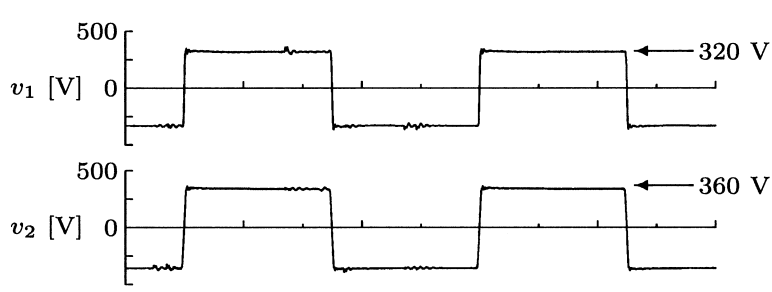

$i_{1}[\mathrm{~A}]$

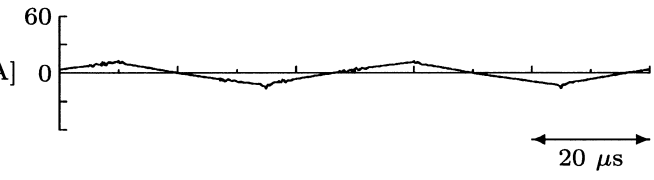

図 $15 E_{1}=320 \mathrm{~V}, E_{2}=360 \mathrm{~V}, \delta=6.5^{\circ}$, $P_{\mathrm{DC}}=0 \mathrm{~kW}$ における実験波形

Fig. 15. Experimental waveforms when $E_{1}=320 \mathrm{~V}$, $E_{2}=360 \mathrm{~V}, \delta=6.5^{\circ}$, and $P_{\mathrm{DC}}=0 \mathrm{~kW}$.

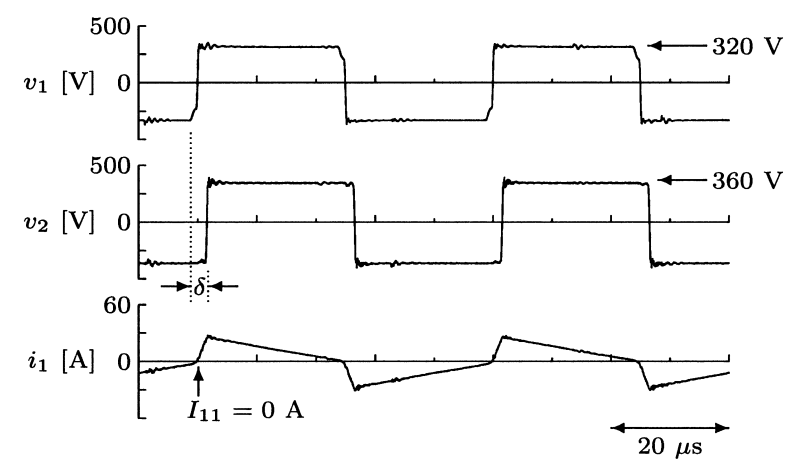

図 $16 E_{1}=320 \mathrm{~V}, E_{2}=360 \mathrm{~V}, \delta=18^{\circ}$, $P_{\mathrm{DC}}=3.8 \mathrm{~kW}$ における実験波形

Fig. 16. Experimental waveforms when $E_{1}=320 \mathrm{~V}$, $E_{2}=360 \mathrm{~V}, \delta=18^{\circ}$, and $P_{\mathrm{DC}}=3.8 \mathrm{~kW}$.

である。そこで, 図 11 の点線部の回路を単巻変圧器と三 相ダイオード整流器に置き換えた。この場合, 双方向電力 伝送試験は不可能であるため, 伝送電力 $P_{\mathrm{DC}}<0$ の場合の みの実験を行った。単巻変圧器の巻数比を調整し, 直流電 圧 $E_{2}$ を $260 \mathrm{~V}$ または $180 \mathrm{~V}$ に設定した。

図 17 は $E_{1}=320 \mathrm{~V}, E_{2}=260 \mathrm{~V}$ の場合の実験波形であ る。このとき, $\delta=-45^{\circ}$ であり, $E_{2}$ から $E_{1} へ 8.6 \mathrm{~kW}$ の電 力が伝送されている $\left(P_{\mathrm{DC}}=-8.6 \mathrm{~kW}\right)$ 。また, $I_{11}=-26 \mathrm{~A}$, $I_{12}=53 \mathrm{~A}$ は, (2), (3) 式から得られる值 $-30 \mathrm{~A}, 57 \mathrm{~A} に$ ほぼ一致しだ。なお， $E_{2}=260 \mathrm{~V}$ の場合に伝送可能な電 力は, 図 9 から $8.7 \mathrm{~kW}$ となり, 図 10 からは $9.6 \mathrm{~kW}$ とな る。したがって，より厳しい条件である $8.7 \mathrm{~kW}$ が伝送可 能な最大電力となる。

図 18 は $E_{1}=320 \mathrm{~V}, E_{2}=180 \mathrm{~V}$ の場合の実験波形であ る。このとき, $\delta=-41^{\circ}$ であり, $E_{2}$ から $E_{1}$ へ $5 \mathrm{~kW}$ の電 力が伝送されている $\left(P_{\mathrm{DC}}=-5 \mathrm{~kW}\right)$ 。図 18 から, Bridge 2 がハードスイッチング動作していることがわかる。ここで, Bridge 1 のスイッチング時の電流 $I_{12}=60 \mathrm{~A}$ は (3) 式から 得られる理論值 $66 \mathrm{~A}$ に良く一致している。一方, Bridge 2

\footnotetext{
† $\delta<0$ であるため, $E_{1}$ と $E_{2}$ を入れ替え， $i_{1}$ の極性を反転して考え
} る。 


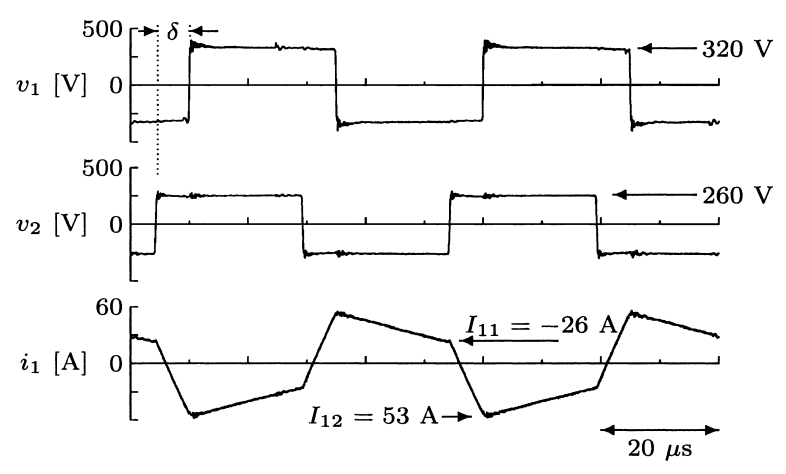

図 $17 E_{1}=320 \mathrm{~V}, E_{2}=260 \mathrm{~V}, \delta=-45^{\circ}$, $P_{\mathrm{DC}}=-8.6 \mathrm{~kW}$ における実験波形

Fig. 17. Experimental waveforms when $E_{1}=320 \mathrm{~V}$, $E_{2}=260 \mathrm{~V}, \delta=-45^{\circ}$, and $P_{\mathrm{DC}}=-8.6 \mathrm{~kW}$.

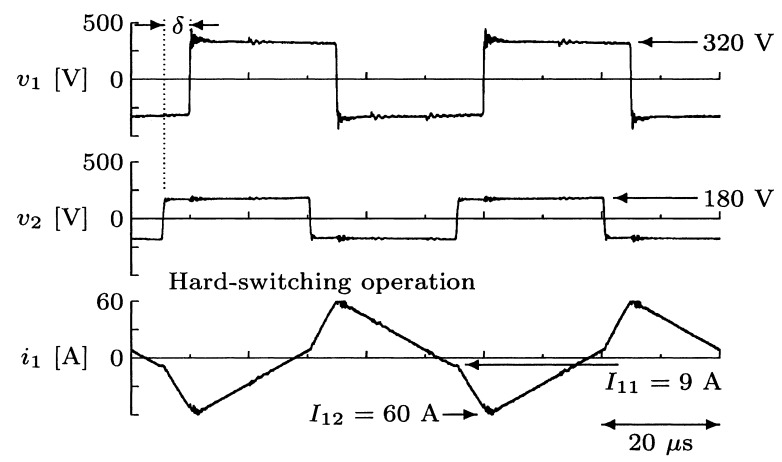

図 $18 E_{1}=320 \mathrm{~V}, E_{2}=180 \mathrm{~V}, \delta=-41^{\circ}$, $P_{\mathrm{DC}}=-5 \mathrm{~kW}$ における実験波形

Fig. 18. Experimental waveforms when $E_{1}=320 \mathrm{~V}$,

$E_{2}=180 \mathrm{~V}, \delta=-41^{\circ}$, and $P_{\mathrm{DC}}=-5 \mathrm{~kW}$.

のスイッチング時の電流 $I_{11}=9 \mathrm{~A}$ と理論值 $-1.7 \mathrm{~A}$ は一致 していない。この誤差は，次節で述べるデッドタイムの影 響によるものと考えられる。

〈7·4〉デッドタイムによる位相差の誤差＼cjkstart図 19 に， デッドタイム $T_{D}$ が位相差 $\delta$ に誤差を生じる原理を示す。 図 19 は図 3 の拡大波形である。直流電圧 $E_{1}<E_{2}$ で Bridge 1 がハードスイッチング動作している。図 19 より, Bridge 1 の交流端電圧 $v_{1}$ はデッドタイム期間を通じて変化せず，デッ ドタイム終了時に $-E_{1}$ から $E_{1}$ に変化する。これに対して ZVS 動作している Bridge 2 の交流端電圧 $v_{2}$ は, デッド夕 イム期間中に $-E_{2}$ から $E_{2}$ に変化する。したがって， $v_{1}$ と $v_{2}$ の実質的な位相差は $\delta-\omega T_{D}$ に近い值となる。

実験回路ではデッドタイム $T_{D}=600 \mathrm{~ns}$ に設定している。 $T_{D}$ は, 1 周期 $T=50 \mu \mathrm{s}$ の場合, $\omega T_{D}=0.0754 \mathrm{rad}=4.3^{\circ}$ に相当する。直流電圧 $E_{1}=320 \mathrm{~V}, E_{2}=360 \mathrm{~V}$ では，(3), (4), (6) 式より, $2.6^{\circ} \leq \delta \leq 10^{\circ}$ で Bridge 1 がハードス イッチング動作する。このような $\delta=2.6^{\circ} \sim 10^{\circ}$ に対し て，デッドタイム $4.3^{\circ}$ は誤差の要因として無視できない。 図 15 , 図 16 では, 制御回路で設定した位相差 $\delta$ と, $v_{1}, v_{2}$ の実質的な位相差の間で誤差を生じたと考えられる。

図 18 では, スイッチング時の電流 $I_{11}$ の理論值が $-1.7 \mathrm{~A}$

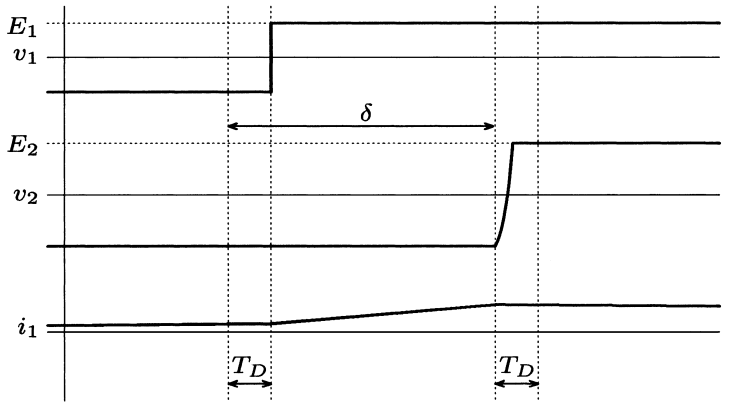

図 19 デッドタイム $T_{D}$ による位相差 $\delta$ の誤差

(Bridge 1 ハードスイッチング動作時)

Fig. 19. Error on the phase shift $\delta$ by the dead time $T_{D}$ when Bridge 1 operates in hard-switchig manner.

であるのに対し，実験值は $9 \mathrm{~A}$ であった。デッドタイム $T_{D}$ の影響を考慮するために， $\delta$ を $\delta-\omega T_{D}$ に置き換えて計算 した理論值は $I_{11}=2.8 \mathrm{~A}$ となる。実験值 $9 \mathrm{~A}$ に比較して誤 差が大きいが，電力損失やゲート駆動回路の遅延など，解 析で無視した要因が複合的に作用していると考えられる。

\section{8. まとめ}

双方向絶縁形 DC/DC コンバータ（10 kW，20kHz）の一 方の直流電圧 $E_{1}=320 \mathrm{~V}$ 一定に維持し, 他方の直流電圧 $E_{2}$ を可変パラメータとして電力損失とピーク電流を理論的 に解析した。次に, $10 \mathrm{~kW}, 20 \mathrm{kHz}$ の実験回路を用いて, $E_{1}=320 \mathrm{~V}$ 一定に維持しつつ, $E_{2}=180 \mathrm{~V} \sim 360 \mathrm{~V}$ の範囲 に変化させた場合の電力伝送試験を行った。安定した電力 伝送を実証し，理論解析結果と実験結果を比較した。さら に，デッドタイムが伝送電力に誤差を生じる現象を考察し た。直流電圧 50～100\%の動作範囲を実現した DC/DCコ ンバータは電気的絶縁を必要とするエネルギー蓄積システ ムなどに応用できる。

(平成 18 年 5 月 11 日受付，平成 18 年 9 月 5 日再受付)

\section{文献}

(1) R.W. De Doncker, D.M. Divan, and M.H. Kheraluwala: "A three-phase softswitched high-power density dc/dc converter for high-power applications", IEEE Trans. IA, Vol.27, No.1, pp.63-73 (1991)

(2) M.H. Kheraluwala, R.W. Gascoigne, and D.M. Divan: "Performance characterization of a high-power dual active bridge dc-to-dc converter", IEEE Trans. IA, Vol.28, No.6, pp.1294-1301 (1992)

(3) H. Li, F.Z. Peng, and J.S. Lawler: "A natural ZVS medium-power bidirectional DC-DC converter with minimum number of devices", IEEE Trans. IA, Vol.39, No.2, pp.525-535 (2003)

(4) F.Z. Peng, H. Li, G.-J. Su, and J.S. Lawler: "A new ZVS bi-directional DC-DC converter for fuel cell and battery application", IEEE Trans. Power Electron., Vol.19, No.1, pp.54-65 (2004)

(5) L. Zhu: "A novel soft-commutating isolated boost full-bridge ZVS-PWM DC-DC converter for bidirectional high power applications", IEEE Trans. Power Electron., Vol.21, No.2, pp.422-429 (2006)

(6) M. Pavlovsky, S.W.H. de Haan, and J.A. Ferreira: "Concept of $50 \mathrm{~kW} \mathrm{dc} / \mathrm{dc}$ converter based on ZVS, quasi-ZCS topology and integrated thermal and electromagnetic design", European Conference on Power Electronics and Applications (EPE), CD-ROM (2005)

(7) F. Krismer, J. Biela, and J.W. Kolar: "A comparative evaluation of isolated bi-directional $\mathrm{dc} / \mathrm{dc}$ converters with wide input and output voltage range", 
IEEE IAS Annual Meeting 2005, Vol.1, pp.599-606 (2005)

(8) H. Akagi: "The next-generation medium-voltage power conversion circuits using ultra-low loss, high-speed power switching devices", JIASC 2003 , Vol.1, pp.183-186 (2003) (in Japanese)

赤木泰文：「超低損失・高速パワーデバイスの使用を前提とした次世 代高圧電力変換回路」, 平 15 電学産業応用部門大, Vol.1, pp.183-186 (2003)

(9) S. Inoue and H. Akagi: "A bi-directional isolated dc/dc converter as a core circuit for 3.3-kV/6.6-kV power conversion systems in the next generation", IEEJ Trans. IA, Vol.126, No.3, pp.211-217 (2006) (in Japanese) 井上重徳・赤木泰文：「次世代 $3.3 \mathrm{kV} / 6.6 \mathrm{kV}$ 電力変換システムのコ ア回路としての双方向絶縁形 DC/DC コンバータ」, 電学論 D, 126, 3, pp.211-217 (2006)

井 上 重 徳 (学生員) 1979 年 1 月 29 日生。 2004 年 3 月東

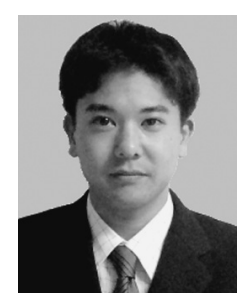
京都立大学大学院工学研究科修士䛅和電気工学専 攻修了同年 4 月, 東京工業大学大学院理丁学研 究科電気電子工学専攻博士後期課程入学, 現在に 至る。次世代半導体電力変換回路に関する研究に 従事。日本学術振興会特別研究員 $\mathrm{DC}$ 。
赤 木 泰 文 （正員） 1951 年 8 月 19 日生。1979 年 3 月東京工

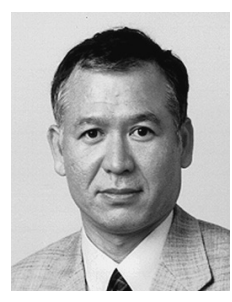
業大学大学院電気工学専攻博士課程修了。工学博 士。長岡技術科学大学助手 ·助教授, 岡山大学教 授を経て, 2000 年 1 月東京工業大学教授。パワー エレクトロニクスの研究に従事。電気学会論文賞 を 4 回, IEEE IAS/PELS Transactions Prize Paper Award 4 回, IEEE IAS Committee Prize Paper Award を 9 回受賞。1996 年 IEEE Felow。1998 年 IEEE IAS/PELS Distinguished Lecturer。2001 年 IEEE William E. Newell Power Elecronics Award。2004 年 IEEE IAS Outstanding Achievement Award。2006 年文部科学大臣表彰・科学技術賞（研究部門）受賞。 